\title{
Antimicrobial resistance in equine faecal Escherichia coli isolates from North West England
}

\author{
Mohamed O Ahmed*1,2, Peter D Clegg ${ }^{\dagger 2}$, Nicola J Williams², Keith E Baptiste ${ }^{\dagger 4}$ and Malcolm Bennett ${ }^{\dagger 3}$
}

\begin{abstract}
Background: Escherichia coli isolates of equine faecal origin were investigated for antibiotic resistance, resistance genes and their ability to perform horizontal transfer.

Methods: In total, 264 faecal samples were collected from 138 horses in hospital and community livery premises in northwest England, yielding 296 resistant E. coli isolates. Isolates were tested for susceptibility to antimicrobial drugs by disc diffusion and agar dilution methods in order to determine minimum inhibitory concentrations (MIC). PCR amplification was used to detect genes conferring resistance to: ampicillin (TEM and SHV beta-lactamase), chloramphenicol (catl, catll, catlll and $\mathrm{cm}$ ), tetracycline (tetA, tetB, tetC, tetD, tet $E$ and tetG), and trimethoprim (dfrA1, dfrA9, dfrA12, dfrA13, dfr7, and dfri7).
\end{abstract}

Results: The proportion of antibiotic resistant isolates, and multidrug resistant isolates (MDR) was significantly higher in hospital samples compared to livery samples (MDR: 48\% of hospital isolates; $12 \%$ of livery isolates, $\mathrm{p}<0.001$ ). Resistance to ciprofloxacin and florfenicol were identified mostly within the MDR phenotypes. Resistance genes included dfr, TEM beta-lactamase, tet and cat, conferring resistance to trimethoprim, ampicillin, tetracycline and chloramphenicol, respectively. Within each antimicrobial resistance group, these genes occurred at frequencies of $93 \%$ (260/279), 91\%, 86.8\% and 73.5\%, respectively; with 115/296 (38.8\%) found to be MDR isolates. Conjugation experiments were performed on selected isolates and MDR phenotypes were readily transferred.

Conclusions: Our findings demonstrate that $E$. coli of equine faecal origin are commonly resistant to antibiotics used in human and veterinary medicine. Furthermore, our results suggest that most antibiotic resistance observed in equine $E$. coli is encoded by well-known and well-characterized resistant genes common to $E$. coli from man and domestic animals. These data support the ongoing concern about antimicrobial resistance, MDR, antimicrobial use in veterinary medicine and the zoonotic risk that horses could potentially pose to public health.

\section{Introduction}

Bacterial resistance to antimicrobials is a global problem, and understanding the molecular basis of resistance acquisition and transmission can contribute to the development of new strategies to combat this phenomenon. Furthermore, a zoonotic component to bacterial antimicrobial resistance has been demonstrated [1-3]. Horses can be a reservoir of antibiotic resistant organisms and genetic determinants of resistance, that may affect veterinary treatment of animals, affect welfare and have economic implications. Such resistance can persist even

\footnotetext{
* Correspondence: mhmd73@lttnet.net

1 Department of Microbiology and Parasitology, Faculty of

Veterinary Medicine, Al Fateh University, Tripoli, PO Box 13662, Libya

+ Contributed equally

Full list of author information is available at the end of the article
}

without selective pressure [1]. Furthermore, antimicrobial use in animals can select for resistance genes that subsequently pose a risk to human public health through compromising the ability to treat infections [2-5]. The use of common antimicrobials in equine veterinary practices, the close contact between humans and horses, along with the risks and consequences such practices place on human health and therapy needs to be reassessed.

Commensal E. coli strains from humans and animals have been reported to express high resistance to common antimicrobial agents, harbouring antibiotic resistance genes such as $d f r A 17$ and $d f r A 12$ [6]. These resistance genes are commonly present on mobile genetic elements such as plasmids and integrons in clinical isolates of Gram-negative microorganisms [4]. Furthermore, resistance genes selected for in non-pathogenic bacteria may 
later transfer the acquired resistance to pathogenic bacterial species $[7,8]$. Thus, normal bacterial flora can play a key role as an acceptor and donor of antimicrobial resistance [9]. It has been suggested that in the UK, antibiotic resistance in $E$. coli of animal origin may arise by acquisition of resistance genes present in MDR bacteria in farm soil. Thus, these bacteria could play an important role in the dissemination of antimicrobial resistance genes to other soil microbes and gastrointestinal bacteria of grazing animals [10].

Whilst several studies in different animals including horses have analysed $E$. coli for their susceptibility to antimicrobial agents and genetic determinants $[1,9,11,12]$, zoonotic components of antimicrobial resistance varies between countries [13] and studies of Enterobacteriaceae of equine origin in the UK are limited. To investigate factors that may influence zoonotic transmission of antibiotic resistant $E$. coli through faecal shedding by hospitalized and non-hospitalized horses we describe the prevalence and mechanisms of antibiotic resistance in $E$. coli isolated from equine faecal samples and analysed by susceptibility testing, PCR analysis and conjugation experiments.

\section{Methods}

\section{Source of isolates}

Faecal samples were collected over a six month period from an equine veterinary hospital and from two livery stables on the Wirral Peninsula, in north-west England. A total of 264 faecal samples were collected from 138 horses; 109 of these faecal samples (from 66 horses) came from the Philip Leverhulme Equine Hospital (PLEH) at the University of Liverpool and 155 faecal samples (from 72 horses) were randomly sampled at livery yards, comprising on average two faecal samples per horse. When scoring for the presence or absence of antibiotic resistant $E$. coli, faecal samples were taken as the unit of analysis. To investigate the antibiotic resistance profiles of $E$. coli shed in faecal samples, three E. coli colonies were isolated at random from each sample using semi-selective media (brilliant green broth and eosin methylene blue agar) and further confirmed biochemically using Api20E (bioMerieux) test.

\section{Antimicrobial Susceptibility testing}

Antimicrobial susceptibility testing was performed using both disc diffusion and agar dilution methods, according to the British Society for Antimicrobial Chemotherapy BSAC guidelines.

\section{Disc diffusion method}

Isolates were then subjected to disc diffusion testing according to the British Society for Antimicrobial Chemotherapy (BSAC) guidelines as described [14]. All faecal
E. coli isolates resistant to at least one antimicrobial agent were stored at $-80^{\circ} \mathrm{C}$, until further analysis. Isolates were tested for resistance to the following antibiotics: ampicillin $(30 \mu \mathrm{g})$ (and to cefotaxime $(30 \mu \mathrm{g})$ and ceftazidime (30 $\mu \mathrm{g})$ for extended resistance to cephalosporines and referred in this paper as potential ESBL producers for ampicillin resistant isolates), apramycin $(30 \mu \mathrm{g})$, chloramphenicol $(30 \mu \mathrm{g})$ (and to florfenicol $(30 \mu \mathrm{g})$ for chloramphenicol resistant isolates), nalidixic acid (30 $\mu \mathrm{g}$ ) (and ciprofloxacin $(1 \mu \mathrm{g})$ for nalidixic acid resistant isolates), tetracycline $(30 \mu \mathrm{g})$, trimethoprim $(2.5 \mu \mathrm{g})$, streptomycin $(10 \mu \mathrm{g})$, spectinomycin $(25 \mu \mathrm{g})$, sulphonamides $(100 \mu \mathrm{g})$ and gentamicin $(10 \mu \mathrm{g})$. Stringent criteria were adopted for defining multidrug drug resistance (MDR), including resistance to at least four classes of antimicrobial agents. Extended resistance to cephalosporins was provisionally assigned following BSAC recommendations and these strains thereafter referred to as potential ESBL producers. To determine florfenicol resistance in chloramphenicol resistant isolates we adopted a criterion of $\mathrm{R} \leq 18 \mathrm{~mm}$ and $\mathrm{R} \leq 13 \mathrm{~mm}$ for apramycin resistance, following personal communication with J. M. Andrews, BSAC.

\section{Minimum inhibitory concentration (MIC) determination using agar dilution method}

The MICs of resistant E. coli isolates were determined for each of the following antibiotics: ampicillin, chloramphenicol, ciprofloxacin, tetracycline and trimethoprim using the agar dilution method as described previously [15], and evaluated according to BSAC guidelines.

\section{Identification of antibiotic resistance genes}

PCR amplification was used to identify genes responsible for resistance to: ampicillin, chloramphenicol, trimethoprim and tetracycline. In total, six different PCR protocols were applied and 18 antibiotic resistant genes were investigated. The method for DNA extraction was adapted from a method described by Kimata et al. [16]. Six PCR protocols were applied to detect specific genes according to the resistance phenotype, as follows: TEM and SHV $\beta$ lactamase genes for isolates exhibiting ampicillin resistance [17]; catI, catII, catIII, [18] and cmlA [19] for chloramphenicol resistance; tet $A$, tet $B$, tet $C$, tetD, tet $E$ and tet $G$ for six genes responsible for tetracycline resistance [20];dfrA1,dfrA9 [21] and dfrA12,dfrA13,dfrA7, $d$ frA17 [22] for trimethoprim resistance genes. PCR products of $d f r A 7$ and $d f r A 17, d f r A 12$ and $d f r A 13$ were cleaved using $20 \mathrm{U} E c o R V$ and pst1 (Sigma) respectively. Positive controls were laboratory strains 7071 (dfr12) and 7082a ( $d f r 17)$. Positive controls for the other resistance genes were DNA samples from bacterial isolates previously characterized and sequenced in-house. Table 1 lists all primer pairs used. 
Table 1: Details of the primers used for PCR protocols.

\begin{tabular}{|c|c|}
\hline Primers sequences 5 ' to $3^{\prime}$ & $\begin{array}{l}\text { amplicon } \\
\text { size (bp) }\end{array}$ \\
\hline $\begin{array}{l}\text { Shv: CACTCAAGGATGTATTGTG, } \\
\text { TTAGCGTTGCCAGTGC }\end{array}$ & 885 \\
\hline $\begin{array}{l}\text { Tem: TCGGGGAAATGTGCGCG, } \\
\text { TGCTTAATCGTGAGGCACC }\end{array}$ & 971 \\
\hline $\begin{array}{l}\text { Catl: AGTTGCTCAATGTACCTATAACC, } \\
\text { TTGTAATTCATTAAGCATTCTGCC }\end{array}$ & 585 \\
\hline $\begin{array}{l}\text { Catll: ACACTTTGCCCTITATCGTC, } \\
\text { TGAAAGCCATCACATACTGC }\end{array}$ & 495 \\
\hline $\begin{array}{l}\text { CatIII: TTCGCCGTGAGCATITTG, } \\
\text { TCGGATGAGTATGGGCAAC }\end{array}$ & 508 \\
\hline $\begin{array}{l}\text { cmlA: CCGCCACGGTGTTGTTGTTATC, } \\
\text { CACCTTGCCTGCCCATCATTAG }\end{array}$ & 698 \\
\hline $\begin{array}{l}\text { tetB: TTGGTTAGGGGCAAGTTTTG, } \\
\text { GTAATGGGCCAATAACACCG }\end{array}$ & 659 \\
\hline $\begin{array}{l}\text { tetC: CTTGAGAGCCTTCAACCCAG, } \\
\text { ATGGTCCTCATCTACCTGCC }\end{array}$ & 418 \\
\hline $\begin{array}{l}\text { tetD: AAACCATTACGGCATTCTGC, } \\
\text { GACCGGATACACCATCCATC }\end{array}$ & 787 \\
\hline $\begin{array}{l}\text { tetA: GCTACATCCTGCTTGCCTTC, } \\
\text { CATAGATCGCCGTGAAGAGG }\end{array}$ & 210 \\
\hline $\begin{array}{l}\text { tetE: AAACCACATCCTCCATACGC, } \\
\text { AAATAGGCCACAACCGTCAG }\end{array}$ & 278 \\
\hline $\begin{array}{l}\text { tetG: GCTCGGTGGTATCTCTGCTC, } \\
\text { AGCAACAGAATCGGGAACAC }\end{array}$ & 210 \\
\hline $\begin{array}{l}\text { dfr1: ACGGATCCTGGCTGTTGGTTGGACGC, } \\
\text { CGGAATTCACCTTCCGGCTCGATGTC }\end{array}$ & 254 \\
\hline $\begin{array}{l}\text { dfr9: ATGAATTCCCGTGGCATGAACCAGAAGAT, } \\
\text { ATGGATCCTTCAGTAATGGTCGGGACCTC }\end{array}$ & 399 \\
\hline $\begin{array}{l}\text { dfrA7, dfrA 17: GTCGCCCTAAAACAAAGTTA, } \\
\text { CGCCCATAGAGTCAAATGT }\end{array}$ & 195 \\
\hline $\begin{array}{l}\text { dfr12, dfr13: CCGTGGGTCGATGTTTGATG, } \\
\text { GCATTGGGAAGAAGGCGTTCAC }\end{array}$ & 485 \\
\hline
\end{tabular}

Primer sequences and amplification protocols were taken from the following sources:: TEM \& SHV $\beta$-lactamase genes [17]; catl, catll, catIII [18]; cmIA [19];tetA, tetB, tetC, tetD, tetE and tet $[$ [20];dfrA1, dfrA9 [21];dfrA12, dfrA13, dfrA7, dfrA17 [22]

\section{E. coli conjugation}

Conjugation experiments were carried out on isolates susceptible to nalidixic acid and resistant to ampicillin (n $=35$ ), using the nalidixic acid resistant $E$. coli $\mathrm{K} 12$ (developed using E. coli NTCC 10536) as a recipient strain. $E$. coli $\mathrm{K} 12$ was inoculated into $20 \mathrm{ml}$ nutrient broths (LabM) and incubated overnight at $37^{\circ} \mathrm{C}$. Resistant E. coli strains (donor strains) were inoculated into separate $3 \mathrm{ml}$ nutrient broths and incubated overnight; $4 \mathrm{ml}$ of recipient strain was then added to the donor strain and incu- bated at $37^{\circ} \mathrm{C}$ for one hour. Broths were then streaked onto agar plates containing nalidixic acid $(30 \mu \mathrm{g} / \mathrm{ml})$ plus ampicillin $(8 \mu \mathrm{g} / \mathrm{ml})$. Plates were incubated for 24 hours. Successful transconjugants were subcultured onto nutrient agar for susceptibility testing by disc diffusion as previously described. The resistance profiles of the transconjugants were compared to the resistance profile of the original strains. Gene profiles of the donor isolates, characterized by PCR, were described prior to the tranconjugation experiments

\section{Statistical analysis}

Data was analysed with SPSS statistical software, using the $\mathrm{z}$ test for comparing two proportions.

\section{Results}

Antibiotic resistant E. coli isolates were obtained from both sources of faeces, but with a significant difference in the prevalence of resistant isolates between the hospital and livery premises. For an overview of the frequency of antibiotic resistant faecal $E$. coli, comparison was made at the level of the faecal sample, the unit probably most closely associated with zoonotic transmission. Among samples from the hospitalized horses, 89/109 contained at least one antibiotic-resistant $E$. coli isolate, whereas only $38 / 155$ of the livery-derived equine samples contained resistant isolates, $(\mathrm{p}<0.001)$. A collection of 296 antibiotic resistant $E$. coli isolates, consisting of 219 and 77 resistant isolates from the hospital and livery premises respectively, were selected for further analysis, allowing comparison of resistance phenotypes (including MDR) in individual isolates (summarised in Table 2). The proportion of MDR resistant isolates, identified by disk diffusion, was significantly greater in the hospital-derived isolates $(106 / 219 ; 48 \%)$ than in livery-derived isolates (9/ $77 ; 12 \%, \mathrm{p}<0.001)$. MIC testing confirmed these resistance phenotypes in $>90 \%$ of the isolates.

\section{Antimicrobial resistance and multidrug resistant (MDR) E.} coli

The number of isolates showing resistance to each antimicrobial agent were: trimethorpim $(n=279)$, tetracycline $(\mathrm{n}=198)$, ampicillin $(\mathrm{n}=191)$, potential ESBLs $(\mathrm{n}=$ 17), chloramphenicol $(n=102)$, florfenicol $(n=14)$, nalidixic acid $(n=72)$, ciprofloxacin $(n=65)$, apramycin $(n=$ $1)$, aminoglycosides $(n=249)$, sulphonamides $(n=282)$ and gentamicin $(\mathrm{n}=59)$ (Table 2). Results obtained through MIC testing were in good agreement (>93\%) with those obtained by the disc diffusion test (Table 2).

Overall, 115 (38.8\%) isolates demonstrated an MDR phenotype (resistance to four or more classes of antibiotics): 106 MDR isolates were of hospital origin and nine 
isolates were from livery premises. The resistance profiles of the MDR isolates fell mostly into three distinct groups: AMP, CHL, TET, TRI, NAL $(\mathrm{n}=27 / 23.4 \%)$; AMP, CHLTET, TRI ( $\mathrm{n}=21 / 18.2 \%)$; AMP, TET, TRI, NAL ( $\mathrm{n}=$ $9 / 7.8 \%)$

\section{Antimicrobial resistance genes}

In total, nine resistance genes were identified (Table 3). Trimethoprim resistance was attributable to $d f r$ genes in 93\% (260/279) at the following frequencies: $d f r 1$ (40.3\%), $d f r 17$ (28\%), $d f r 12(17.3 \%)$ and $d f r 9(0.3 \%)$. Of the tetracycline resistant isolates, $86.8 \%(172 / 198)$ were positive by PCR for tet genes, with tet $B$ the most prevalent gene (71\%), followed by tet $A$ at $18 \%$ and $\operatorname{tet}(A+B)$ at $11 \%$. Amplicons of the catI gene were obtained from $73.5 \%$ (75/102) of chloramphenicol resistant isolates, all of which were of hospital origin. Only one of these was also resistant to florfenicol. Of the ampicillin resistant isolates, the TEM $\beta$-lactamase genes was identified in 91\% $(174 / 191)$ and only one isolate was positive for the SHV $\beta$-lactamase genes.

\section{Conjugation experiments}

Eight transconjugants (8/35) were obtained, and all were from hospital isolates (Table 4). The resistance profiles of the transconjugants were re-confirmed by disc diffusion testing and found to be identical to those of the donors. The resistance phenotype AMP, CHL, TET, TRI was the dominant $(n=6)$ followed by AMP, TET, TRI $(n=2)$.

\section{Discussion}

Our results show that hospitalized horses are more likely to shed antibiotic resistant $E$. coli strains, and their faeces are more likely to harbour MDR than those of horses in livery premises. The significantly higher prevalence of antibiotic resistance and of MDR found in hospitalized horses in this study fits well with previous observations [23]. All the horses at the PLEH are referrals from private veterinary practices, so many of the horses will have undergone treatment, which may include prior antibiotic administration. Thus, the higher prevalence of resistant E. coli in hospitalized horses could reflect conditions prior to arrival at the PLEH. Transportation and other stress factors have also been shown to increase the shedding of antibiotic resistant enteric bacteria [23], and this may also have influenced the prevalence of resistant $E$. coli strains in samples collected from the PLEH.

Ampicillin resistance in E. coli isolates described in this paper was largely associated with TEM $\beta$-lactamase genes, with only one isolate positive for SHV $\beta$-lactamase genes. This agrees with other reports that TEM $\beta$-lactamase genes (i.e. TEM-1 $\beta$-lactamase gene) are the most prevalent in ampicillin resistant $E$. coli of animal origin, as well as being commonly reported in human $E$. coli isolates of hospital origin [23]. Furthermore, this study identified 17 isolates as resistant to cephalosporins (i.e. potential ESBL producers), all of which were positive for TEM $\beta$-lactamase genes, with MICs for ampicillin $\geq 256$ $\mu \mathrm{g} / \mathrm{ml}$ (except for two isolates against, which the MICs = $128 \mu \mathrm{g} / \mathrm{ml})$. The prevalence of extended spectrum betalactamase (ESBL) resistance in European countries of $E$. coli human isolates is reported to be around 3.9\% [24] with variations between countries. ESBL-targeted drugs are being used more frequently, but may result in mutations of TEM and SHV $\beta$-lactamase genes, as well as the widely prevalent $c t x-m$ types [25]. For the potential ESBL producers more identification and confirmation is

Table 2: Resistance profiles and MDR frequency in $E$. coli isolates from equine faecal samples.

\begin{tabular}{|c|c|c|c|c|}
\hline Abs & $\begin{array}{l}\text { No. of faecal samples } \\
\text { with at least one } \\
\text { resistant E. coli; disc } \\
\text { diffusion method (\%) }\end{array}$ & $\begin{array}{l}\text { No E. coli isolates } \\
\text { exhibiting resistant } \\
\text { phenotype }\end{array}$ & $\begin{array}{l}\text { Proportion of isolates } \\
\text { resistant by disc } \\
\text { diffusion method, } \\
\text { which were } \\
\text { confirmed by MIC }\end{array}$ & $\begin{array}{c}\text { No MDR-positive } \\
\text { faecal samples } \\
\text { (\% faecal samples) }\end{array}$ \\
\hline AMP & 89 (33.7\%) & 191 & $93.0 \%$ & 57 (21.6\%) \\
\hline APR & $1(0.4 \%)$ & 1 & - & $1(0.4 \%)$ \\
\hline NAL & $36(13.6 \%)$ & 72 & - & 35 (13.3\%) \\
\hline CIP & $28(10.6 \%)$ & 65 & $93.8 \%$ & $28(10.6 \%)$ \\
\hline $\mathrm{CHL}$ & 49 (18.6\%) & 102 & $100 \%$ & 47 (17.8\%) \\
\hline FLO & $9(3.4 \%)$ & 14 & - & $9(3.4 \%)$ \\
\hline TET & $92(34.8 \%)$ & 198 & $93.4 \%$ & $57(21.6 \%)$ \\
\hline TRI & $135(51.0 \%)$ & 279 & $95.0 \%$ & 57 (21.6\%) \\
\hline
\end{tabular}

Abbreviation: ABs, antimicrobials; AMP, ampicillin; APR, apramycin; NAL, nalidixic acid; CIP, ciprofloxacin; CHL, chloramphenicol; FLO, florfenicol; TET, tetracyclin; TRI, trimethoprim 
Table 3: Summary of results showing the identification and distribution of antibiotic resistance genes in $E$. coli isolates from equine faecal samples taken from hospital and livery premises.

\begin{tabular}{|c|c|c|c|c|}
\hline $\begin{array}{l}\text { Antibiotic(No. of } \\
\text { resistant } \\
\text { isolates investigated) }\end{array}$ & $\begin{array}{c}\text { Source and } \\
\text { number }(\mathrm{N}) \text { of isolates }\end{array}$ & Identified by PCR & $\begin{array}{c}\text { Not identified by } \\
\text { PCR }\end{array}$ & $\begin{array}{l}\text { Antibiotic resistance } \\
\text { gene composition } \\
\text { tested by PCR (details } \\
\text { in table legend) }\end{array}$ \\
\hline AMP (191) & $\begin{array}{c}\text { Hospital } n=177 \\
\text { Livery } n=14\end{array}$ & $\begin{array}{c}169 \\
5\end{array}$ & $\begin{array}{l}8 \\
9\end{array}$ & $\begin{array}{c}\text { TEM \& SHV } \beta \text { - } \\
\text { lactamase genes }\end{array}$ \\
\hline CHL (102) & $\begin{array}{l}\text { Hospital } n=97 \\
\text { Livery } n=5\end{array}$ & $\begin{array}{c}75 \\
0\end{array}$ & $\begin{array}{c}22 \\
5\end{array}$ & catl cat $/ 1$ cat $/ 1 / \mathrm{cm} / A$ \\
\hline TET (198) & $\begin{array}{l}\text { Hospital } n=177 \\
\text { Livery } n=21\end{array}$ & $\begin{array}{c}154 \\
18\end{array}$ & $\begin{array}{c}23 \\
3\end{array}$ & $\begin{array}{c}\text { tetB tetA tetC tetD tetE } \\
\text { tet } G\end{array}$ \\
\hline TRI (279) & $\begin{array}{l}\text { Hospital } n=209 \\
\text { Livery } n=70\end{array}$ & $\begin{array}{c}195 \\
65\end{array}$ & $\begin{array}{c}14 \\
5\end{array}$ & $\begin{array}{c}\text { dfrA1 dfrA17 dfrA12 } \\
\text { dfrA9 } d f r A 7, d f r A 13\end{array}$ \\
\hline
\end{tabular}

All genes listed were tested by PCR amplification using gene-specific primer pairs listed in Table 1. Genes positively identified by PCR are

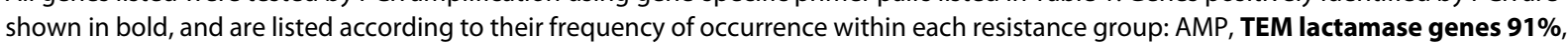
SHV $\beta$-lactamase genes $0.6 \%$; CHL, catl 73.5\%; TET, tetB 71\%, tetA 18\%,tet A+B 11\%; TRI, dfrA $140.3 \%$, dfrA17 28\%, dfrA12 $17.3 \%$, dfrA9 $\mathbf{0 . 3} \%$. Those genes failed to give rise to detectable levels of PCR product are listed in normal type.

Abbreviations: AMP, ampicillin; CHL, chloramphenicol; TET, tetracycline; TRI, trimethoprim

required and further genotypic analysis in needed. Our results showed that $E$. coli resistance genes from horses are similar to those found in other animals and humans, however these need further investigation, specifically by sequencing the TEM $\beta$-lactamase PCR products.

In our study, the tet $B$ gene was the most prevalent (71\%) tetracycline resistance gene, followed by tet $A$ (18\%), and no other tet gene was identified. This preva-

\section{Table 4: Resistant isolates that transferred resistance via conjugation, listed according to their resistance phenotypes.}

\begin{tabular}{|c|c|}
\hline Antibiogram & $\begin{array}{l}\text { Donor genes contributing to the } \\
\text { phenotype of each isolate }\end{array}$ \\
\hline \multirow[t]{6}{*}{ AMP, CHL, TET, TRI $(n=6)$} & $\begin{array}{c}\text { dfrA17, tetA, catl,TEM } \beta \text {-lactamase } \\
\text { genes }\end{array}$ \\
\hline & $d f r A 17$, catl,TEM $\beta$-lactamase genes \\
\hline & $\begin{array}{c}\text { tet } A, d f r 1, d f r A 17, \text { TEM } \beta \text {-lactamase } \\
\text { genes }\end{array}$ \\
\hline & $\begin{array}{c}d f r A 17, d f r A 12, \text { tetB,TEM } \beta \text {-lactamase } \\
\text { genes }\end{array}$ \\
\hline & $\begin{array}{c}\operatorname{dfr} A 12, \text { tet } A \text {, tet } B, \text { TEM } \beta \text {-lactamase } \\
\text { genes, catl }\end{array}$ \\
\hline & $\begin{array}{c}d f r A 1, d f r A 1, \text { tetB,TEM } \beta \text {-lactamase } \\
\text { genes, catl }\end{array}$ \\
\hline \multirow[t]{2}{*}{ AMP, TET, TRI $(n=2)$} & $\begin{array}{c}d f r A 17, d f r A 12, \text { tet } B, \text { TEM } \beta \text {-lactamase } \\
\text { genes }\end{array}$ \\
\hline & $d f r A 1$, tetB,TEM $\beta$-lactamase genes \\
\hline
\end{tabular}

Abbreviations: $\mathrm{AMP}$, ampicillin; $\mathrm{CHL}$, chloramphenicol; TET, tetracycline; TRI, trimethoprim; $\mathrm{n}=$ number of isolates lence pattern has also been reported in E. coli strains from various animals, including horses [26]. The tet $B$ gene has the widest host range among gram-negative pathogens [27]. In gram-negative bacteria, tet $A$ and tet $B$ efflux genes are widely distributed and normally associated with plasmids, of which most are conjugative [27] and there is evidence for a correlation between the widespread distribution of tetracycline resistance genes and the sub-therapeutic antimicrobial use of tetracycline [28]. However, in the UK, tetracyclines are used relatively rarely in equine veterinary medicine, suggesting that the tet resistance genes identified here may have been acquired by co-selection mechanisms, as discussed below.

The catI gene, responsible for most of the plasmidmediated resistance to chloramphenicol, was the only cat gene detected in the chloramphenicol resistant isolates. Most of chloramphenicol resistant isolates (47/102) were of the MDR phenotype (Table 2), suggesting that resistance to chloramphenicol is likely to be part of a multiple resistance system. The non-enzymatic chloramphenicol resistance gene $(\mathrm{cmlA})$ also confers resistance to florfenicol. However, that $\mathrm{cmlA}$ gene was not identified by PCR, suggesting that the observed flofenicol resistance was possibly due to flo gene, although some chloramphenicol resistant genes can also be responsible for flofenicol resistance [29]. The use of chloramphenicol in UK veterinary medicine is generally restricted to topical application as a treatment for ophthalmic conditions, and is hardly ever used systemically. Chloramphenicol resistance was almost exclusively found in hospital-derived samples indicating that, as with tetracycline resistance, chloram- 
phenicol resistance has most probably been co-selected via linked trimethoprim and ampicillin resistance genes.

A large proportion (93\%) of the trimethoprim resistant isolates were positive for at least one of the $d f r$ genes, that are commonly encoded on mobile genetic elements. Particularly, $d f r A 1$ has spread rapidly on the transposon $\operatorname{Tn} 7$ to become the most prevalent gene responsible for trimethoprim resistance in the UK [30], and the most prevalent in our study, followed by $d f r A 12$ and $d f r A 17$. The $d f r A 9$ was found only in one isolate in the present study. The $d f r A 9$ gene, first reported in porcine E. coli strains, has also been reported in veterinary isolates and spread to human strains probably as a consequence of the extensive use of potentiated sulphonamide products (e.g. Sulfadiazine/trimethoprim) in veterinary medicine [31]. Reportedly, $d f r$ genes are mostly conjugally transferable $[6,32]$.

A previous study on horses has documented in vitro conjugal transfer of antibiotic resistant genes between genera of Enterobacteriaceae [12]. In studies on E. coli isolates of human origin, the wide dissemination of $d f r A 17$ in urinary E. coli isolates is due mainly to the horizontal transfer of class 1 integrons, via conjugative plasmids [32]. Similarly, horizontal transfer through conjugative plasmids has been reported to be responsible for the wide dissemination of mobile genetic elements (e.g. class 1 integrons) in E. coli isolates from humans and animals [6]. Classes of integrons are widely reported in Enterobacteriaceae from animals $[6,10]$ and in E. coli of animal origin, including horses [1]. Some of our isolates possess the ability to transfer resistance to a recipient $(E$. coli K12), see table 4, clearly indicating that the resistance is harboured on mobile genetic elements.

Our MIC determination and genetic analysis of resistant isolates suggests that in horses, antibiotic resistance is conferred by the same E. coli resistance genes found in other animal species. In total, 115/296 (38.8\%) of our isolates showed MDR. Interestingly, MDR transferred in the conjugation studies, in which all transconjugants showed resistance to ampicillin and trimethoprim (table 4), indicating that both resistance profiles are encoded on mobile genetic elements. Antibiotic resistance can arise in the absence of selective pressures where antibiotic resistance genes are linked on a mobile genetic element; in these cases, exposure to a single antimicrobial agent has been shown to give rise to co-selection of multiple antibiotic resistance genes. Furthermore, stopping treatment, and consequent removal of selective pressure, does not necessarily lead to the loss of resistance $[4,33]$. Resistance to a range of antimicrobials can thus be selected for by administrating one, or a subset, of antimicrobials [9]. The shedding of resistant bacteria could thus produce a reservoir of resistant bacteria in the environment $[4,10]$. This type of mechanism may account for the presence of genes conferring resistance to tetracyclines and chloramphenicol, which are very rarely used therapeutically in equine veterinary medicine in the UK. Further work is required to define the multidrug resistant mechanisms, that may be responsible for the high level of prevalence of the resistance profiles (AMP, CHL, TET, TRI, NAL; AMP, CHL, TET, TRI; AMP, TET, TRI, NAL) we have identified. That most of these were from hospital sources might explain the possible role of antimicrobials in the dissemination and development of resistance in this environment.

\section{Conclusions}

To our knowledge this is the first study of antibiotic resistant $E$. coli in equine faeces in the UK. Many of the genes we have identified as responsible for antibiotic resistance in equine E. coli are commonly found in other domestic animals and humans. Antibiotic resistance found in horses probably originates from, and is selected by, the same sources and mechanisms as in other animal species. Thus, in the UK, horses may be both recipients, and sources of the zoonotic transmission of antibiotic resistance and MDR, as well as providing an extensive reservoir for antimicrobial resistance genes.

\section{Competing interests}

The authors declare no relationship (commercial or otherwise) that may constitute a dual or conflicting interest.

\section{Authors' contributions}

MOA was responsible for study design, data collection and writing the manuscript. NJW provided strains and resistance data, and PDC organized samples collection within the hospital. All the authors contributed to the study design, the analysis of the results and writing this manuscript. All authors read and approved the final manuscript.

\section{Acknowledgements}

Authors are grateful to all staff members at Philip Leverhulme Equine Hospital $(P L E H)$ and the livery stables for their help and support throughout this work.

\section{Author Details}

1Department of Microbiology and Parasitology, Faculty of Veterinary Medicine, Al Fateh University, Tripoli, PO Box 13662, Libya, 2Department of Comparative Molecular Medicine, School of Veterinary Science, University of Liverpool, Leahurst, Chester High Road, Neston, CH64 7TE, UK, ${ }^{3}$ Department of Animal and Population Health, School of Veterinary Science, University of Liverpool, Leahurst, Chester High Road, Neston, CH64 7TE, UK and

${ }^{4}$ Department of Large Animal Sciences, Faculty of Life Sciences, University of Copenhagen, Taastrup, 2630, Denmark

Received: 22 January 2010 Accepted: 7 April 2010

Published: 7 April 2010

\section{References}

1. Kadlec K, Schwarz S: Analysis and distribution of class 1 and class 2 integrons and associated gene cassettes among Escherichia coli isolates from swine, horses, cats and dogs collected in the BfT-GermVet monitoring study. J Antimicrob Chemother 2008, 62(3):469-473.

2. Nunnery J, Angulo FJ, Tollefson L: Public health and policy. Prev Vet Med 2006, 73(2-3):191-195.

3. Angulo FJ, Nunnery JA, Bair HD: Antimicrobial resistance in zoonotic enteric pathogens. Rev Sci Tech 2004, 23(2):485-496. 
4. Alekshun MN, Levy SB: Molecular mechanisms of antibacterial multidrug resistance. Cell 2007, 128(6):1037-1050.

5. Scott Weese J: Antimicrobial resistance in companion animals. Anim Health Res Rev 2008, 9(2):169-176.

6. Kang HY, Jeong YS, Oh JY, Tae SH, Choi CH, Moon DC, Lee WK, Lee YC, Seol SY, Cho DT, et al: Characterization of antimicrobial resistance and class 1 integrons found in Escherichia coli isolates from humans and animals in Korea. J Antimicrob Chemother 2005, 55(5):639-644.

7. Phillips I, Casewell M, Cox T, De Groot B, Friis C, Jones R, Nightingale C, Preston R, Waddell J: Does the use of antibiotics in food animals pose a risk to human health? A critical review of published data. J Antimicrob Chemother 2004, 53(1):28-52.

8. Wassenaar TM: Use of antimicrobial agents in veterinary medicine and implications for human health. Crit Rev Microbiol 2005, 31(3):155-169.

9. Saenz Y, Brinas L, Dominguez E, Ruiz J, Zarazaga M, Vila J, Torres C: Mechanisms of resistance in multiple-antibiotic-resistant Escherichia coli strains of human, animal, and food origins. Antimicrob Agents Chemother 2004, 48(10):3996-4001.

10. Srinivasan V, Nam HM, Sawant AA, Headrick SI, Nguyen LT, Oliver SP: Distribution of tetracycline and streptomycin resistance genes and class 1 integrons in Enterobacteriaceae isolated from dairy and nondairy farm soils. Microb Ecol 2008, 55(2):184-193.

11. Dunowska M, Morley PS, Traub-Dargatz JL, Hyatt DR, Dargatz DA: Impact of hospitalization and antimicrobial drug administration on antimicrobial susceptibility patterns of commensal Escherichia coli isolated from the feces of horses. J Am Vet Med Assoc 2006, 228(12):1909-1917.

12. Vo AT, van Duijkeren E, Fluit AC, Gaastra W: Characteristics of extendedspectrum cephalosporin-resistant Escherichia coli and Klebsiella pneumoniae isolates from horses. Vet Microbio/ 2007, 124(3-4):248-255.

13. de Jong A, Bywater R, Butty P, Deroover E, Godinho K, Klein U, Marion H, Simjee S, Smets K, Thomas V, et al: A pan-European survey of antimicrobial susceptibility towards human-use antimicrobial drugs among zoonotic and commensal enteric bacteria isolated from healthy food-producing animals. J Antimicrob Chemother 2009, 63(4):733-744.

14. Andrews JM: BSAC standardized disc susceptibility testing method (version 7). J Antimicrob Chemother 2008, 62(2):256-278.

15. Andrews JM: Determination of minimum inhibitory concentrations. $J$ Antimicrob Chemother 2001, 48(Suppl 1):5-16.

16. Kimata K, Shima T, Shimizu M, Tanaka D, Isobe J, Gyobu Y, Watahiki M, Nagai Y: Rapid categorization of pathogenic Escherichia coli by multiplex PCR. Microbiol Immunol 2005, 49(6):485-492.

17. Pitout JD, Thomson KS, Hanson ND, Ehrhardt AF, Moland ES, Sanders CC: beta-Lactamases responsible for resistance to expanded-spectrum cephalosporins in Klebsiella pneumoniae, Escherichia coli, and Proteus mirabilis isolates recovered in South Africa. Antimicrob Agents Chemother 1998, 42(6):1350-1354

18. Vassort-Bruneau C, Lesage-Descauses MC, Martel JL, Lafont JP, ChaslusDancla E: CAT III chloramphenicol resistance in Pasteurella haemolytica and Pasteurella multocida isolated from calves. J Antimicrob Chemother 1996, 38(2):205-213.

19. Keyes K, Hudson C, Maurer JJ, Thayer S, White DG, Lee MD: Detection of florfenicol resistance genes in Escherichia coli isolated from sick chickens. Antimicrob Agents Chemother 2000, 44(2):421-424.

20. Ng LK, Martin I, Alfa M, Mulvey M: Multiplex PCR for the detection of tetracycline resistant genes. Mol Cell Probes 2001, 15(4):209-215.

21. Gibreel A, Skold O: High-level resistance to trimethoprim in clinical isolates of Campylobacter jejuni by acquisition of foreign genes ( $\mathrm{dr} 1$ and dfr9) expressing drug-insensitive dihydrofolate reductases. Antimicrob Agents Chemother 1998, 42(12):3059-3064.

22. Lee JC, Oh JY, Cho JW, Park JC, Kim JM, Seol SY, Cho DT: The prevalence of trimethoprim-resistance-conferring dihydrofolate reductase genes in urinary isolates of Escherichia coli in Korea. J Antimicrob Chemother 2001, 47(5):599-604.

23. Brinas L, Zarazaga M, Saenz Y, Ruiz-Larrea F, Torres C: Beta-lactamases in ampicillin-resistant Escherichia coli isolates from foods, humans, and healthy animals. Antimicrob Agents Chemother 2002, 46(10):3156-3163.

24. Hanberger H, Arman D, Gill H, Jindrak V, Kalenic S, Kurcz A, Licker M, Naaber P, Scicluna EA, Vanis V, et al.: Surveillance of microbial resistance in European Intensive Care Units: a first report from the Care-ICU programme for improved infection control. Intensive Care Med 2009, 35(1):91-100

25. Paterson DL, Bonomo RA: Extended-spectrum beta-lactamases: a clinical update. Clin Microbiol Rev 2005, 18(4):657-686.

26. Bryan A, Shapir N, Sadowsky MJ: Frequency and distribution of tetracycline resistance genes in genetically diverse, nonselected, and nonclinical Escherichia coli strains isolated from diverse human and animal sources. Appl Environ Microbiol 2004, 70(4):2503-2507.

27. Chopra I, Roberts M: Tetracycline antibiotics: mode of action applications, molecular biology, and epidemiology of bacterial resistance. Microbiol Mol Biol Rev 2001, 65(2):232-260

28. Stine OC, Johnson JA, Keefer-Norris A, Perry KL, Tigno J, Qaiyumi S, Stine MS, Morris JG Jr: Widespread distribution of tetracycline resistance genes in a confined animal feeding facility. Int J Antimicrob Agents 2007, 29(3):348-352.

29. Singer RS, Patterson SK, Meier AE, Gibson JK, Lee HL, Maddox CW: Relationship between phenotypic and genotypic florfenicol resistance in Escherichia coli. Antimicrob Agents Chemother 2004, 48(10):4047-4049.

30. Towner KJ, Brennan A, Zhang Y, Holtham CA, Brough JL, Carter GI: Genetic structures associated with spread of the type la trimethoprim-resistant dihydrofolate reductase gene amongst Escherichia coli strains isolated in the Nottingham area of the United Kingdom. J Antimicrob Chemother 1994, 33(1):25-32

31. Jansson C, Franklin A, Skold O: Spread of a newly found trimethoprim resistance gene, dhfrlX, among porcine isolates and human pathogens. Antimicrob Agents Chemother 1992, 36(12):2704-2708.

32. Yu HS, Lee JC, Kang HY, Jeong YS, Lee EY, Choi CH, Tae SH, Lee YC, Seol SY, Cho DT: Prevalence of dfr genes associated with integrons and dissemination of dfrA17 among urinary isolates of Escherichia coli in Korea. J Antimicrob Chemother 2004, 53(3):445-450.

33. Sundqvist M, Geli P, Andersson DI, Sjolund-Karlsson M, Runehagen A, Cars H, Abelson-Storby K, Cars O, Kahlmeter G: Little evidence for reversibility of trimethoprim resistance after a drastic reduction in trimethoprim use. J Antimicrob Chemother 2009.

doi: $10.1186 / 1476-0711-9-12$

Cite this article as: Ahmed et al., Antimicrobial resistance in equine faecal Escherichia coli isolates from North West England Annals of Clinical Microbiology and Antimicrobials 2010, 9:12

\section{Submit your next manuscript to BioMed Centra and take full advantage of:}

- Convenient online submission

- Thorough peer review

- No space constraints or color figure charges

- Immediate publication on acceptance

- Inclusion in PubMed, CAS, Scopus and Google Scholar

- Research which is freely available for redistribution
C) BioMed Central 